\title{
Integrating Android Smartphone and Microcontroller System for Controlling and Monitoring The Two Wheels Electric-Bike
}

\author{
Rustam Asnawi ${ }^{1}$, Ariadie Chandra Nugraha ${ }^{2}$, Andik Asmara ${ }^{3}$, I Gede Dangin \\ ${ }^{123}$ Department of Electrical Engineering Education, Engineering Faculty \\ Universitas Negeri Yogyakarta \\ Yogyakarta, Indonesia \\ rustam@uny.ac.id ${ }^{1}$; ariadie@uny.ac.id ${ }^{2}$; andikasmara@uny.ac.id ${ }^{3}$
}

\begin{abstract}
The objective of this research is to design and to develop an electronic control and monitoring systems for a Brushless DC (BLDC) motor that is employed to run a two wheels electric-bike by integrating the android smartphone and microcontroller via Bluetooth device. The overall research passed through four phases: (1) needs analysis and identification, (2) designing the system, (3) implementation and development, and (4) testing the developed-system. The results of this research is an electronic system that able to communicate and integrate a microcontroller Atmega 328, Bluetooth devices and android smartphones for controlling and monitoring the Brushless DC motor of the two wheels electric-bike. The general performance of the data communication between android smartphone and the developed electronic control system (via Bluetooth) will be effective and work properly within 0 upto 15 meters. The android application can be installed in various brands of android smartphone and versions of the android operating system. The electric-bike can be switched on and off using an android smartphone which has been installed the developed application inside. The electric power condition of the batteries can be real time displayed in the android's screen.
\end{abstract}

Keywords_electric-bike, Bluetooth, microcontroller, android

\section{INTRODUCTION}

In Indonesia, the transportation sector consumes about $27 \%$ of the total final energy consumption per 2013[1]. The number would increase continuously since the selling price of fueled motor cycle is down gradually. The number of fueled motor cycle is always increasingly; while the wide of roads is tend to stable. This will affect in more severe traffic-jammed. Air pollution and noise pollution resulting from the engines of the fueled motor cycle will adversely affect the human health and life. If there is no any regulation, management and real action especially from the government, then it all will accumulate and ends into global warming.

Thus, the electric-vehicle offer more environment friendly in transportation, since there is no inflicting air pollution or noise pollution. Development a bicycle powered by electricity (electric-bike) in particular, is one of alternate in middledistance transportation which environment friendly and it can be used by all ages.
On the other hand, a smart mobile phone (Smartphone) with the Android operating system is one of the most popular devices for human telecommunication today [2][3]. Now smartphone is not a luxury thing anymore since most of people from any level of society have such smartphone. Starting from here then emerging an idea to add features inside the existing electric-bike such as controlling and monitoring system for the electric-bike based on an android smartphone. By adding the system, the driver will be easier for operating and monitoring the electric-bike. From direct physic observation in the electricbike, the weaknesses and shortcomings of the two-wheel electric-bike are first, the monitoring system for the voltage and current of the battery that used to operating the brushless DC (commonly shortened as BLDC) motor still uses a conventional way.

BLDC motor is an improvement of a conventional DC motors that currently many used for the actuator or propulsion in automotive industry. Comparing with the DC brushed motors or DC conventional induction motors, BLDC motors have many advantages which are as follows reliability and high efficiency, vibration and noise disruption are low, smaller size and stronger, better dynamic response, high torque, high speed range and durable.

Monitoring the battery's voltage in which to operate the BLDC motor commonly uses the pointing of the needle from an analog voltmeter. Even a particular version of an electricbike has no battery's voltage monitoring system. Consequently, if that electric-bike is run and there is no control and monitoring mechanism for the battery's voltage then it would likely reach a condition in which the battery energy is truly empty (run out energy up to $0 \%$ ). This will accelerate the damage to the battery. However, an electronic automation system for monitoring and controlling the power of the BLDC motor is needed and urgently to be created. In this case, the driver while driving that electric-bike in front of him there is a particular panel that displays the real-time battery's energy condition. Since most of everyone now has an android smartphone, it is better and more efficient while the control and monitoring system is also based on Android smartphone. 
Technically, designing the electronic automation system for controlling and monitoring BLDC motor is based on microcontroller Atmega 328 (equivalent with Arduino) [4][5][6]. Then, data communication between android smartphone and that electronic automation system uses Bluetooth technology [7][8]. HC-05 Bluetooth module is utilized for the communication module device at the microcontroller side[9]. Note Figure 1.

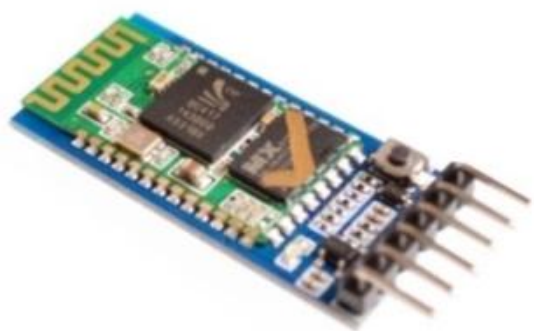

Fig. 1. Bluetooth Serial Module HC-05

HC-05 Bluetooth module works at a $2.4 \mathrm{GHz}$ radio frequency. For developing communication using Bluetooth Module HC-05 is required at least 4 connectors that are for +5 volt dc power supply, Ground, TXD (transmit data) and RXD (receive data). Consider Figure 1.

Second, commonly the design of the ignition key is like on conventional model as in motorcycle's ignition key. It is so prone to fall down and missing. From that, then rising an idea to create another alternative of such ignition key, here also using android-based smartphone. The rider to switch on and off the BLDC motor of the electric-bike just taps a button of an Android application program that already installed in an Android smartphone. So the electric-bike rider just to install the application on their Android smartphone to start operating the electric-bike and also with that Android smartphone he is able to control and monitor the bike.

For this purpose, an integrated electronic system is needed to manage and control the data communication between android smartphone and the electronic control system for the BLDC motors. This is approached by microcontroller based and using Bluetooth technology[9]. The electronic system should be able to integrate the data communication between the Android smartphone, microcontroller (with the Bluetooth HC05 module) and BLDC motor with its batteries. Microcontroller type of Atmega 328 is used in this research with some of consideration; most of this microcontroller is similar to the Arduino microcontroller type that has been popular today. However, using Atmega 328 have benefit on costless [6]. Then for developing the Android application, an online software application developer special for Android namely App Inventor can be utilized[10][11]. App Inventor is provided by the Massachusetts Institute of Technology.

\section{RESEARCH METHODS}

Overall, this research is approached by the four main stages, those are: (1) needs analysis and identification, (2) system design, (3) implementation and development, and (4) testing and evaluation.

The needs analysis and identification consists of hardware and software needs analysis and identification. The system design stage is divided into hardware design and software design. Then, for the implementation and development stage mainly realizing the design of hardware and software into a prototype of the electric-bike system. Finally the testing process, here all parts of the control system of the electric-bike are examined and tested part by part.

The data gathering for this research uses direct observation to the prototype. While trying and operating the product prototype, then it was observed and examined directly part-bypart. The results of the examination per part were recorded and collecting it as its performance.

As the data analysis, all data from the results of all observation processes were classified (and recorded) based on the main parts of the electric-bike system. After that, the data was analyzed descriptively per part which certainly reflects the quality of the related part of the prototype. If the results of the data analysis are not in accordance with the purpose of this research, it is necessary to do re-evaluation and re-testing again to the prototype product in order to in accordance with the purpose of research.

\section{RESULT AND DISCUSSION}

From the results of needs analysis were obtained hardware identification. Hardware components that were required to develop such a system are as follows:

1. DC Motor, Specifications: voltage: DC 48Volt, brushless, power: 350Watt.

2. Battery, Specifications: Lithium-ion battery, 48Volt DC, $10 \mathrm{Ah}$

3. Battery charger, Specifications: input voltage: $220 \mathrm{Vac}$, for charging: 48Volt battery system, Charging time: 3 hours

4. Microcontroller: Arduino (ATmega 328)

5. Bluetooth Serial Module HC-05

In the design stage, the main electronic circuit diagram of the control system for controlling the BLDC motor was created (see Figure 2). Next, an electronic circuit of the electrical power supply for the BLDC motor was designed (see Figure 3).

After conducting the design process, then the next stage is to realize (implementation stage) all the results in the design stage. From the hardware design, it can be developed and realized an electronic control and monitoring system based on Atmega 328 for BLDC motor and its batteries. Also the power supply unit especially for the BLDC motor. Furthermore the code programs that suite for the Atmega 328 microcontroller was created. Here, for programming Atmega 328 is required a special software that is Open-source Arduino software (or Arduino IDE). It can be downloaded freely at the official Arduino website. 


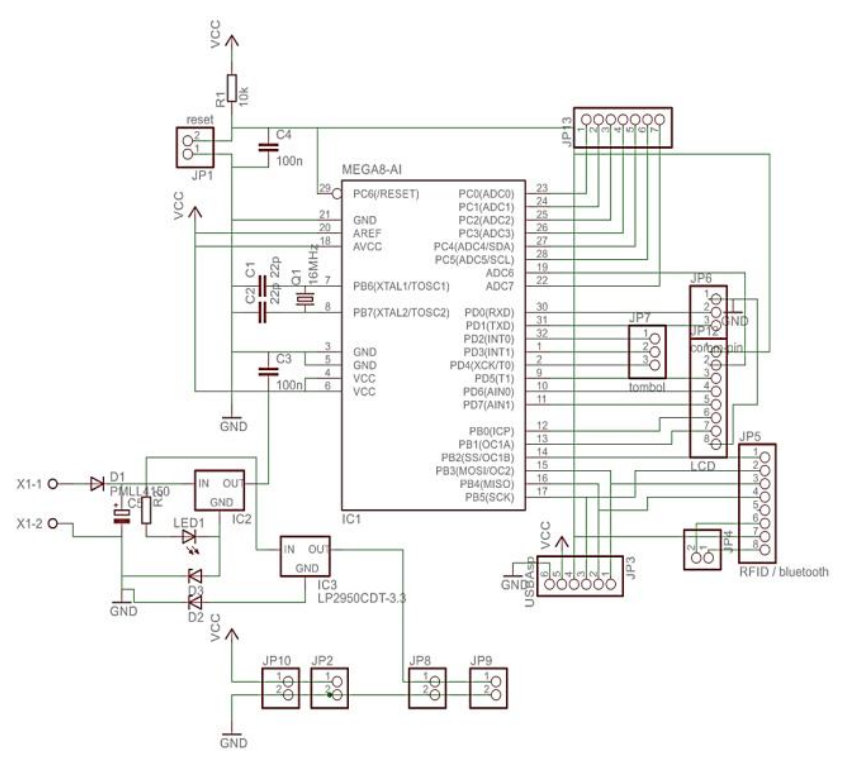

Fig. 2. The main electronic circuit of the BLDC motor control system

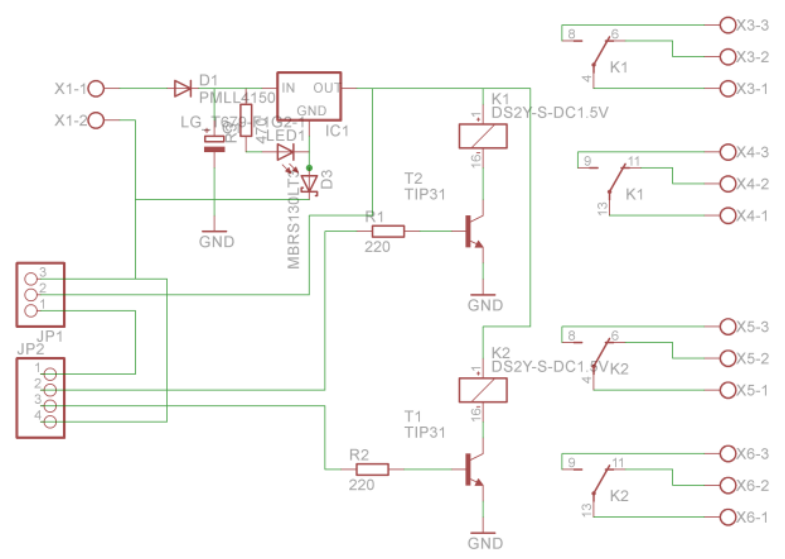

Fig. 3. The electronic circuit of the power supply for the BLDC motor
The next work in this stage is to perform and build a blockbased and online Android programming using App Inventor 2, see Figure 4 [12]. The goal is to develop an Android application in which it able to connect and communicate between such Android smartphone and Atmega 328 system using Bluetooth interface technology.

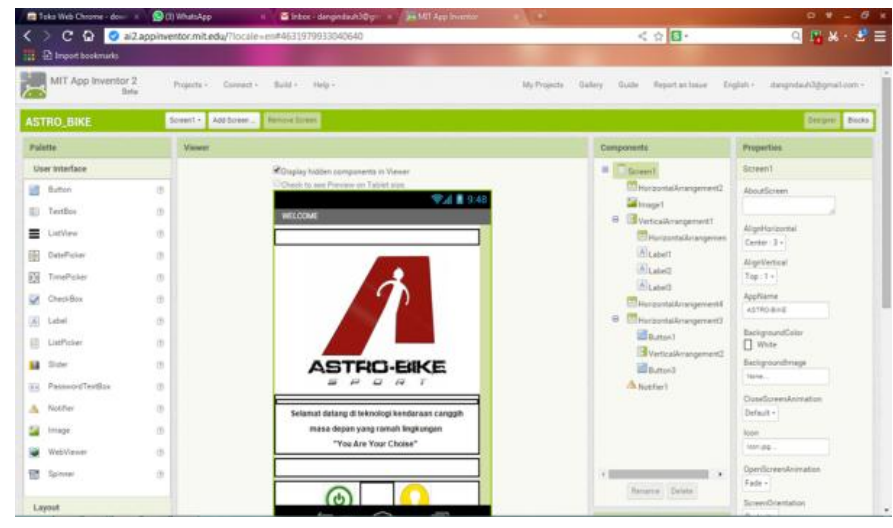

Fig. 4. Building the Android application using App Inventor

The last stage is testing and evaluation. Testing of the electronic control system for BLDC motor is approached by per block (or per part) testing of the system, and then followed by testing the performance of the overall system. Table I shows the results of the per block testing and examination.

TABLE I. The List OF RESUlt OF PER Block (PART) TESTING

\begin{tabular}{|c|c|c|c|c|}
\hline No. & Tested parts & characteristics & result & Information \\
\hline 1. & Battery & Voltage and current test & Max $56.8 \mathrm{v}$ & battery specifications: \\
\hline & & capabilities & Min 48 volt & Lithium ion, 48volt capacity $9 \mathrm{AH}$ \\
\hline 2. & BLDC Motor Driver & $\begin{array}{l}\text { Testing voltage on } 48 \text { Volt } \\
\text { and current requirements }\end{array}$ & $\begin{array}{l}\text { Max 56.8v } \\
16 \text { Ampere }\end{array}$ & 3 phase BLDC with Hall-effect sensor \\
\hline 3. & $\begin{array}{l}\text { Interface Motor Driver with } \\
\text { Microcontroller System }\end{array}$ & $\begin{array}{l}\text { Testing performance by } \\
\text { taking into account the } \\
\text { input-output }\end{array}$ & Input voltage $56.8-48 \mathrm{~V}$ & Under 48v automatic driver Protek \\
\hline 4. & $\begin{array}{l}\text { Interface microcontroller and } \\
\text { Bluetooth serial module HC-05 }\end{array}$ & $\begin{array}{l}\text { Testing performance with } \\
\text { consider to the Bluetooth } \\
\text { connectivity }\end{array}$ & $\begin{array}{c}\text { Smartphone can be connected to the } \\
\text { ATmega328 system by Bluetooth } \\
\text { device. }\end{array}$ & $\begin{array}{l}\text { The connection between Bluetooth } \mathrm{HC} 05 \\
\text { and the Bluetooth in smartphone should be } \\
\text { initiated first. After that, it can be in auto } \\
\text { connection }\end{array}$ \\
\hline 5. & $\begin{array}{l}\text { The Android application as a } \\
\text { product using App Inventor }\end{array}$ & Black box testing & Testing with android version $4.2-6.0$ & $\begin{array}{l}\text { Link: } \\
\text { Ai2.appinventor.mit.edu/ }\end{array}$ \\
\hline
\end{tabular}




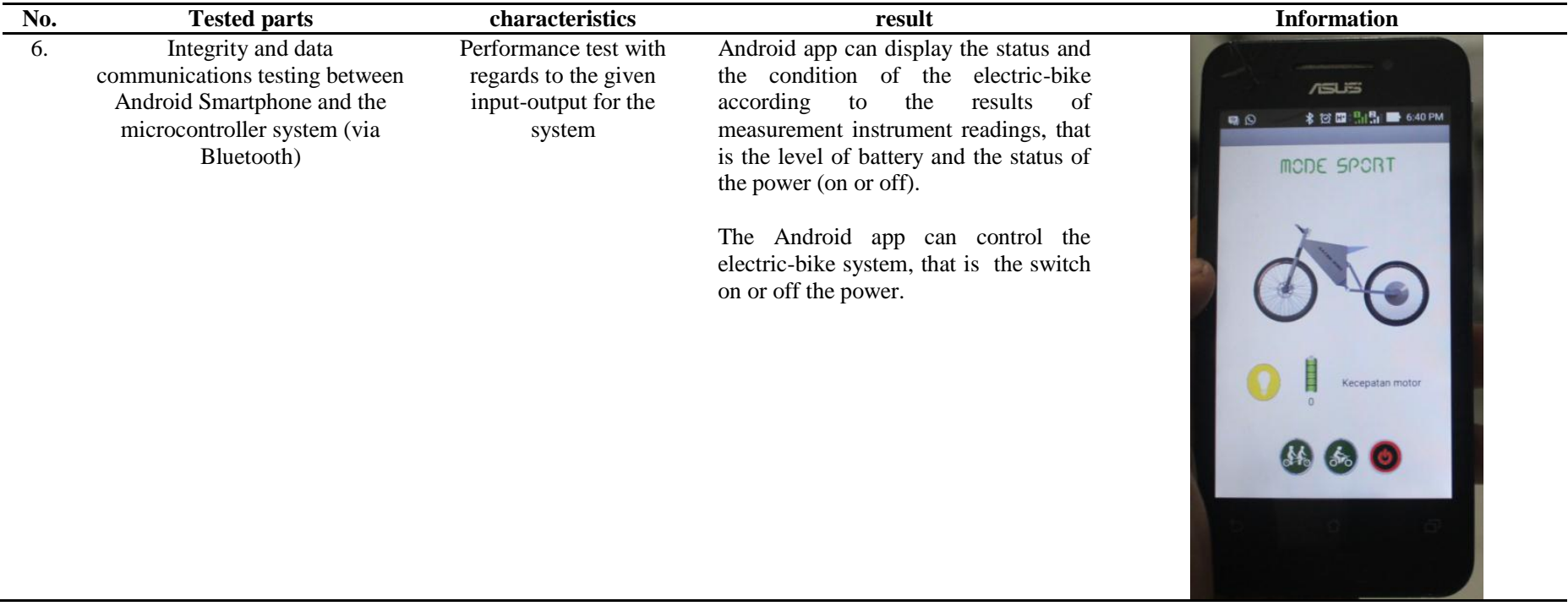

\section{Results of the Electronic Control Systems Testing}

Reliability test: the objective is to obtain the maximum distance that the Android is still permitted in order to turn on the electric-bike. Table II presents the data of the test result.

TABLE II. RESULTS OF THE ELECTRIC-BIKE IGNITION BY SWITCHING ON THE ANDROID SMARTPHONE'S POWER BUTTON (IN VARIETY OF DISTANCES)

\begin{tabular}{ccclll}
\hline No. & Distance $(\mathbf{m})$ & Test-1 & Test-2 & Test-3 & Information \\
\hline 1. & 1 & yes & yes & yes & good response \\
2. & 2 & yes & yes & yes & good response \\
3. & 3 & yes & yes & yes & good response \\
4. & 4 & yes & yes & yes & good response \\
5. & 5 & yes & yes & yes & good response \\
6. & 6 & yes & yes & yes & good response \\
7. & 7 & yes & yes & yes & good response \\
8. & 8 & yes & yes & yes & good response \\
9. & 9 & yes & yes & yes & good response \\
10. & 10 & yes & yes & yes & good response \\
11. & 11 & yes & yes & yes & good response \\
12. & 12 & yes & yes & yes & good response \\
13. & 13 & yes & yes & yes & good response \\
14. & 14 & yes & yes & yes & good response \\
15. & 15 & yes & yes & yes & good response \\
16. & 16 & No & No & No & Lost connection \\
17. & 17 & No & No & No & Lost connection \\
\hline
\end{tabular}

a. *) "yes": means that the bike can be operated (power on), and "No": means electric bikes cannot be operated (power off).

Good response means, as fast as the power button on the android screen is tapped, the power led indicator on the electric-bike will light on (the electric-bike ready to run immediately just withdraw the velocity lever). The lost connection means that the connection of the data communication between Android smartphones and the electric-bike system is disconnected.

Reliability test: the objective is to obtain the maximum distance between the bike and android smartphone so it can stably turn off the power of the electric-bike.
TABLE III. THE RESULTS OF THE SWITCH OFF THE ELECTRIC-BIKE BY PUTTING AWAY THE ANDROID SMARTPHONE LEFT FROM THE BIKE (IN VARIETY OF DISTANCE)

\begin{tabular}{ccclll}
\hline No. & $\begin{array}{c}\text { Distance } \\
(\mathbf{M})\end{array}$ & Test-1 *) & Test-2 & Test-3 & Information \\
\hline 1. & 2 & yes & yes & yes & good response \\
2. & 3 & yes & yes & yes & good response \\
3. & 4 & yes & yes & yes & good response \\
4. & 5 & yes & yes & yes & good response \\
5. & 6 & yes & yes & yes & good response \\
6. & 7 & yes & yes & yes & good response \\
7. & 8 & yes & yes & yes & good response \\
8. & 9 & yes & yes & yes & good response \\
9. & 10 & yes & yes & yes & good response \\
10. & 11 & yes & yes & yes & good response \\
11. & 12 & yes & yes & yes & good response \\
12. & 13 & yes & yes & yes & good response \\
13. & 14 & yes & yes & yes & good response \\
14. & 15 & yes & yes & yes & good response \\
15. & 16 & No & No & No & Lost connection \\
16. & 17 & No & No & No & Lost connection \\
\hline
\end{tabular}

From the results of both reliability testing above show that the maximum distance for allowing the Android smartphone can still be connected with the electric-bike via Bluetooth is 15 meters. If the distance is increasing more than 15 meters, and both devices (smartphone and the bike) have already connected before, then the Bluetooth connection is automatically disconnected. Thus the electrical power supply from batteries to the BLDC motor would be automatically disconnected. If both devices were not connected each other, then the Android smartphone will not be able to turn on the power of the electric-bike.

Reliability test: the objective is to verify the validity of the data monitoring of the battery voltage on Android smartphone. Compare with the actual data from manual measurement using instrument. 
TABLE IV. THE RESULTS OF THE VERIFICATION TESTING ON BATTERY VOLTAGE

\begin{tabular}{cccccc}
\hline No. & $\begin{array}{c}\text { display } \\
\text { level } \\
\text { tension }\end{array}$ & $\begin{array}{c}\text { Vbat-1 } \\
\text { (volts) }\end{array}$ & $\begin{array}{c}\text { Vbat-2 } \\
\text { (volt) }\end{array}$ & $\begin{array}{c}\text { vbat } \\
\text { rata2 }\end{array}$ & $\begin{array}{c}\text { Speed of the } \\
\text { Bike }\end{array}$ \\
\hline 1. & $100 \%$ & 54.0 & 53.3 & 53.65 & $40 \mathrm{~km} / \mathrm{h}$ \\
2. & $90 \%$ & 53.2 & 52.7 & 52.95 & $40 \mathrm{~km} / \mathrm{h}$ \\
3. & $80 \%$ & 52.6 & 52.3 & 52.45 & $39 \mathrm{~km} / \mathrm{h}$ \\
4. & $70 \%$ & 52.2 & 52.0 & 52.1 & $38 \mathrm{~km} / \mathrm{h}$ \\
5. & $60 \%$ & 51.9 & 51.5 & 51.7 & $37 \mathrm{~km} / \mathrm{h}$ \\
6. & $50 \%$ & 51.4 & 51.0 & 51.2 & $36 \mathrm{~km} / \mathrm{h}$ \\
7. & $40 \%$ & 50.9 & 49.4 & 50.15 & $35 \mathrm{~km} / \mathrm{h}$ \\
\hline
\end{tabular}

Compatibility test: the objective is to determine the compatibility of the developed Android application which is installed into different types and brands of Android smartphone.

TABLE V. RESULTS OF THE COMPATIBILITY TESTING OF THE ANDROID APPLICATION

\begin{tabular}{|c|c|c|c|c|c|c|}
\hline No & brands & Series & $\mathbf{O S}$ & $\begin{array}{l}\text { Ver- } \\
\text { sion }\end{array}$ & result & \\
\hline 1 & ASUS & Zenfone 4 & Lolipop & 5.0 & $\begin{array}{l}\text { Compatible } \\
\text { Success }\end{array}$ & $\&$ \\
\hline 2 & ASUS & Zenfone 5 & Lolipop & 5.0 & $\begin{array}{l}\text { Compatible } \\
\text { Success }\end{array}$ & $\&$ \\
\hline 3 & Lenovo & & Jelly bean & 4.2 .2 & $\begin{array}{l}\text { Compatible } \\
\text { Success }\end{array}$ & $\&$ \\
\hline 4 & Samsung & & Jelly bean & 4.2 .2 & $\begin{array}{l}\text { Compatible } \\
\text { Success }\end{array}$ & $\&$ \\
\hline 5 & LG & $\begin{array}{l}\text { Google } \\
\text { Nexus } 5\end{array}$ & marshmallow & 6.0 .1 & $\begin{array}{l}\text { Compatible } \\
\text { Success }\end{array}$ & $\&$ \\
\hline
\end{tabular}

Table V shows that the android application was successfully developed in this research (using App Inventor), and it can be installed and operated in various types of smartphone and its operating system.

Meanwhile, after completing the forth testing (3 reliabilities testing, 1 compatibility testing), it can be explained that concretely already established two-way (bidirectional) data communication between Android smartphones and the electronic control system of the twowheel electric-bike via Bluetooth. Data from Android smartphone that led to the electronic control system is a signal to turn on and turn off the power of the BLDC Motor of the electric-bike. While data from the electronic control system of the electric-bike that led to Android smartphone is the data signals and information about the battery voltage level. So from the results of the overall tests, it is clear that the integration and simultaneously two-way data communications between android smartphone and the electronic control systems of electric-bike via Bluetooth are already established and as expected. The functionality of each component that are (1) microcontroller Atmega 328 as the "brain" of the electronic control system, (2) Bluetooth devices with specific data formats that embedded in ATmega328 system and exist in Android smartphones, and (3) the Android smartphone itself can already be integrated to develop a new and more complex systems. The new system has a specific performance but more powerful.

\section{CONCLUSION}

The electronic control system for BLDC motor to run the two wheels electric-bike has been successfully designed and developed. The main components are microcontroller ATmega328, Bluetooth serial module HC-05, and Android smartphone with its application.

The electronic control system based on ATmega328 (for the BLDC motor) with embedded Bluetooth module and the Android smartphone can be integrated and performing a new system that has the performance as follows: data communication between the smartphone and the electronic control system via Bluetooth can be run optimally at distances between 0 up to 15 meters (without hard obstruction). Android application can be used to turn on and turn off the power of the electric-bike, and displays the battery voltage level in real time. If the bike in the oncondition, then kept away from the smartphones more than 15 meters, the power of the electric-bike would be automatically switched off. Android application program can be installed in various brands of smartphones and various versions of the android operating system.

\section{REFERENCES}

[1] Dewan Energi Nasional, Outlook Energi Indonesia 2014, Kementerian Energi dan Sumber Daya Mineral Republik Indonesia, 2014.

[2] Vincent James, 99.6 Percent of New Smartphones run Android or iOS, www.theverge.com, Feb 2017.

[3] Callaham John, Google says there are now 1.4 billion active Android devices worldwide, www.androidcentral.com, Sep 2015

[4] Badamasi Y.A., The Working Priciple of An Arduino, 11th International Conference on Electronics, Computer and Computation (ICECCO), IEEE, 2014

[5] Galadima A.A., Arduino as a Learning Tool, 11th International Conference on Electronics, Computer and Computation (ICECCO), IEEE, 2014

[6] D'Ausilio A., Arduino: A low-cost multipurpose lab. Equipment, Psychonomic Society,Inc., Springer, DOI 10.3758/s13428-011-0163z, 2011

[7] [7] Kumar S., Lee S.R., Android Based Smart Home System with Control via Bluetooth and Internet Connectivity, IEEE ISCE 1569945213,2014

[8] R. Piyare and M.Tazil, Bluetooth based home automation system using cell phone, in IEEE $15^{\text {th }}$ International Symposium on Consumer Electronics (ISCE), Singapore, 2011, pp.192-195

[9] Pahuja R., Kumar N., Android Mobile Phone Controlled Bluetooth Robot using 8051 Microcontroller, International Journal of Scientific Engineering and Research (IJSER) vol.2, issue 7, ISSN:2347-3878, 2014.

[10] Prabowo MAA., Novianto S., Additional Street Berbasis App Inventor, Jurnal Teknologi Informasi Techno.com vol.12, no.2, 2013, pp.90-103.

[11] Hsu Yu-Chang, Ching Yu-Hui, Mobile App Design for Teaching and Learning: Educators' Experiences in an Online Graduate Course, The International Review of Research in Open and Distance Learning vol.14, No. 4., 2013.

[12] Wolber D., App Inventor and Real-world Motivation, Proceedings of the 42nd ACM Technical Symposium on Computer Science Education, 2011 pp.601-606. 